\title{
Implications of purinergic receptor-mediated intracellular calcium transients in neural differentiation
}

\author{
Talita Glaser ${ }^{1}$, Rodrigo R Resende ${ }^{2}$ and Henning Ulrich ${ }^{1 *}$
}

\begin{abstract}
Purinergic receptors participate, in almost every cell type, in controlling metabolic activities and many physiological functions including signal transmission, proliferation and differentiation. While most of P2Y receptors induce transient elevations of intracellular calcium concentration by activation of intracellular calcium pools and forward these signals as waves which can also be transmitted into neighboring cells, P2X receptors produce calcium spikes which also include activation of voltage-operating calcium channels. P2Y and P2X receptors induce calcium transients that activate transcription factors responsible for the progress of differentiation through mediators including calmodulin and calcineurin. Expression of P2X2 as well as of P2X7 receptors increases in differentiating neurons and glial cells, respectively. Gene expression silencing assays indicate that these receptors are important for the progress of differentiation and neuronal or glial fate determination. Metabotropic receptors, mostly P2Y1 and P2Y2 subtypes, act on embryonic cells or cells at the neural progenitor stage by inducing proliferation as well as by regulation of neural differentiation through NFAT translocation. The scope of this review is to discuss the roles of purinergic receptor-induced calcium spike and wave activity and its codification in neurodevelopmental and neurodifferentiation processes.
\end{abstract}

Keywords: Purinergic receptors, Intracellular calcium transients, Neural differentiation, Neural fate specification

The importance of establishing cellular replacement therapies is increasing nowadays. These therapies are based on stem cells due to their capability of originating other cell types by differentiation, or even releasing factors that can reduce inflammatory responses and promote homing of adult stem cells of the proper patient to the site of injury. However, the molecular mechanisms of development, cell differentiation, successful cell engraftment and recruitment of endogenous stem cells in case of injury need yet to be resolved. Thus, major efforts are being undertaken in order to understand the process of neural differentiation, mediated by intracellular signaling triggered by external and internal stimuli, resulting in differential gene transcription pattern and neural phenotype determination.

\footnotetext{
* Correspondence: henning@iq.usp.br

${ }^{1}$ Departamento de Bioquímica, Instituto de Química, Universidade de São Paulo, Avenida Professor Lineu Prestes, 748, São Paulo CEP 05508-900, Brazil Full list of author information is available at the end of the article
}

\section{Intracellular calcium signaling and purinergic receptors}

Among different pathways coordinating intracellular signaling, the most prominent is intracellular calcium signaling (ICS), controlling various cellular processes including proliferation, motility, apoptosis and differentiation [1]. ICS is impressively diverse and consists of mechanisms that differ in frequency, amplitude and spatio-temporal patterning depending on an extensive molecular repertoire of signaling components. The free intracellular calcium concentration $\left(\left[\mathrm{Ca}^{2+}\right]_{\mathrm{i}}\right)$ of a resting cell is in the range of 10-100 nM. Following physiological stimulation, $\left[\mathrm{Ca}^{2+}\right]_{\mathrm{i}}$ levels can rise up to $1-2 \mu \mathrm{M}$ concentrations. ICS is codified by the peak amplitude and frequency of $\left[\mathrm{Ca}^{2+}\right]_{\mathrm{i}}$ transients, promoted by the entry of external $\mathrm{Ca}^{2+}$ through $\mathrm{Ca}^{2+}$ channels or the release of $\mathrm{Ca}^{2+}$ from internal stores. These internal stores are deposited within internal membrane structures such as the endoplasmic reticulum (ER). Following activation of G-protein-coupled receptors, phospholipase C- $\beta$

\section{Biomed Central}


(PLC- $\beta$ ) cleaves phosphatidylinositol 4,5-bisphosphate, releasing diacylglycerol and inositol-1,4,5-trisphosphate (IP3) which diffuses into the cell for activation of IP3 receptors (IP3R) and releasing $\mathrm{Ca}^{2+}$ from the ER. Moreover, $\mathrm{Ca}^{2+}$ enters the cytosol and activates ryanodine receptor (RYR) channels following activation of voltageoperated channels (VOCs), or receptor-operated channels (ROCs); this process is called $\mathrm{Ca}^{2+}$-induced $\mathrm{Ca}^{2+}$ release [2-4].

There are mainly two types of spontaneous intracellular $\mathrm{Ca}^{2+}$ transients: waves and spikes. The first one is mediated by IP3R and/or RYR activation and involves sensitivity to $\left[\mathrm{Ca}^{2+}\right]_{\mathrm{i}}$ levels. This $\mathrm{Ca}^{2+}$ entry pathway is active at resting potential and is amplified by $\mathrm{Ca}^{2+}$ release from intracellular stores, and increases $\left[\mathrm{Ca}^{2+}\right]_{i}$ to a lower level than that attained by spikes. In the presence of gap junctions connecting cells, these intracellular waves can spread to neighboring cells, thereby coordinating neural activity and physiological processes of many cells [5,6]. Compared to $\mathrm{Ca}^{2+}$ spikes, waves reveal a lower frequency with a mean duration of more than 30s, as observed in growth cones; their generation does not depend on action potentials. Waves occur locally and decay with distance from the site of initiation.

Calcium spikes depend on $\mathrm{Ca}^{2+}$ influx through VOCs or ROCs and $\mathrm{Ca}^{2+}$ release from intracellular stores $\left(\mathrm{Ca}^{2+}\right.$ induced $\mathrm{Ca}^{2+}$ release via $\left.\mathrm{RYR}\right)$, and achieve mean $\left[\mathrm{Ca}^{2+}\right]_{\mathrm{i}}$ levels of $500 \mathrm{nM}$. They are characterized by their frequency (mean duration approximately 10s), and occur throughout an excitable cell, since they involve $\mathrm{Ca}^{2+}$-dependent action potentials.

Spontaneous $\mathrm{Ca}^{2+}$ spike frequency in cultured neurons initially varies from $1-10 / \mathrm{h}$ and then declines. Similar patterns of spike activity were observed in neural tube stages in vivo [2,7] and during neuronal differentiation of embryonal carcinoma (CSC, a model for pluripotent embryonic stem cells) and adult bone marrow mesenchymal (hMSC) stem cells [8,9]. Notably, these low frequencies of calcium transients regulate gene transcription and are suggested to be essential for the progress of neural differentiation and phenotype specification [2,10-12].

Chemical and electrical signals, mediated by metabotropic and ionotropic receptors and VOCs promote intracellular calcium signaling and subsequent induction of differentiation. Adenosine 5'-triphosphate (ATP)activated metabotropic and ionotropic receptors, also denominated as purinergic receptors, have drawn a lot of attention, due to their wide expression in almost every cell including stem cells. These receptors belong to the first neurotransmitter receptors expressed during development $[13,14]$. ATP is the mainly purinergic messenger molecule and is released from cells in physiological conditions by exocytosis, transporters or even lysosomes.
When the release occurs by damaged cells in an uncontrolled manner, ATP contributes to cell death and disease states. Once released into the extracellular space, ATP is degraded by ectonucleotidases producing the signaling molecules adenosine diphosphate (ADP), adenosine monophosphate [15] and adenosine [14]. Based on pharmacological and structural properties, purinergic receptors are divided into metabotropic P1 and P2Y receptors as well as $\mathrm{P} 2 \mathrm{X}$ ionotropic receptors.

P1 receptors subtypes are selective for adenosine and are classical seven-transmembrane metabotropic receptors coupled to several families of $\mathrm{Gi}$, Go and Gs proteins. There are four types of adenosine receptors (A1, A2A, $\mathrm{A} 2 \mathrm{~B}$ and $\mathrm{A} 3$ ) differing by pharmacological and functional properties [15]. A1 and A3 receptors exert inhibitory effects on adenylyl cyclase activity (mediated through $\mathrm{Gi} / \mathrm{o}$ proteins) and also regulate PLC- $\beta$ activity and thus IP3 synthesis [14]. P2 receptor subtypes are activated by ATP, ADP, uridine-5'-triphosphate (UTP), uridine-5'-diphosphate (UDP) or UDP-glucose. P2 receptors are further divided into P2X and P2Y subtypes based on their structural characteristics [13].

P2X receptors as ATP-gated cationic $\left(\mathrm{Na}^{+} / \mathrm{K}^{+} / \mathrm{Ca}^{2+}\right)$ channels [13,16], are assembled in trimeric form as homomeric or heteromeric receptors from seven subunits (P2X1-P2X7). Recombinant P2X1, P2X2, P2X3, P2X4, P2X2/3, P2X2/6, P2X4/6, P2X1/5 as well as P2X7 receptors, when activated in a silent environment of cells not expressing any endogenous purinergic receptor, were all shown to be permeable for $\mathrm{Ca}^{2+}$ [17]. P2X receptors are mostly expressed by excitable cells, and $\mathrm{Ca}^{2+}$ entry through P2X receptor channels provides an important regulation mechanism of physiological responses in vivo, while aberrant $\mathrm{Ca}^{2+}$ entry, mostly mediated by P2X7 receptors, is suggested to be involved in pathophysiological conditions such as cell death, neuroinflammation and excitotoxic brain damage during epilepsy [18-22].

Metabotropic P2Y purinergic receptors activated by ATP, ADP, UTP, UDP or UDP glucose are composed by P2Y1,2,4,6,11,12,13,14 subtypes based on phylogenetic similarity [14]. P2Y1,2,4,6,11 subtypes are coupled to Gq/G11 proteins activating PLC- $\beta$, thus inducing IP3mediated $\mathrm{Ca}^{2+}$ release from the ER $[13,14,23]$. P2Y12,13,14 receptors inhibit adenylyl cyclase activity via $\mathrm{Gi} /$ o proteins. These latter-mentioned receptors also participate in regulating $\left[\mathrm{Ca}^{2+}\right]_{\mathrm{i}}$ levels. For instance, P2Y receptor subtypes acting via $\mathrm{Gi} /$ o proteins can regulate $\mathrm{N}$-type $\mathrm{Ca}^{2+}$ channel activity [24-26]. P2Y receptors are expressed in the central and autonomic nervous systems as well as by most nonexcitatory cells where they exert long-term effects by regulating crucial cellular functions including proliferation and differentiation [14].

Recent studies have focused on changes of expression patterns and functions of this receptor family during 
differentiation from embryonic into neuronal cells $[8,27]$. The developmental fate of differentiating stem cells depends on the 'niche', in which the cells exist, and several associated signaling systems have been pinpointed $[28,29]$. In this review, we discuss the importance of ICS for the differentiation process of stem cells into neural cells with special emphasis on purinergic receptor function during $\mathrm{Ca}^{2+}$ signaling.

\section{Purinergic receptors triggering ICS in the nervous system and neural differentiation}

Many of the signal transduction pathways that control cell metabolism, survival and differentiation are activated by elevation of $\left[\mathrm{Ca}^{2+}\right]_{\mathrm{i}}$ levels following activation of purinergic receptors. Moreover, numerous experimental data point at essential functions of purinergic signaling in neural differentiation and brain development. It has been well established that purinergic receptor activation triggers $\left[\mathrm{Ca}^{2+}\right]_{\mathrm{i}}$ transients that are involved in developmental processes of the embryo [30,31]. Pioneering studies of Nicholas Spitzer that the progress of neurogenesis and phenotype determination, such as neurotransmitter specification, is encoded by naturally occurring patterns of $\left[\mathrm{Ca}^{2+}\right]_{\mathrm{i}}$ transients, are in agreement with essential functions of purinergic receptor signaling for cortex development. As detailed above, $\mathrm{P} 2 \mathrm{X}$ receptors by inducing $\mathrm{Ca}^{2+}$ influx generate repetitive $\left[\mathrm{Ca}^{2+}\right]_{i}$ transients in spike form with activation of RYR while P2Y receptors act through IP3-induced intracellular $\mathrm{Ca}^{2+}$ release which then is propagated in wave form (Figure 1).

Ionotropic purinergic receptors also participate in regulation of neural proliferation and neurogenesis by inducing calcium spikes. In agreement, P2X2 and P2X6 receptor subunit expression was enhanced together with the enrichment of neurons during differentiation of rat embryonic telencephalon [32]. For instance, P2X receptor activity is suggested to be involved in hippocampal neurogenesis by inducing proliferation of hippocampal progenitor cells [33]. The P2X7 receptor usually participates in pore formation, but its abundant presence in synaptic structure suggests a role in synaptic plasticity establishment [26]. Some experimental data indicate that P2X7 receptors, rather than connexin-hemichannels, mediate ATP release and amplification of astrocytic intercellular $\mathrm{Ca}^{2+}$ signaling [34]. In view of that, it will be worth to study the participation of P2X7 receptors in

\section{A}

$$
\text { P2X1-7 } \longrightarrow \text { Calcium Spikes }
$$
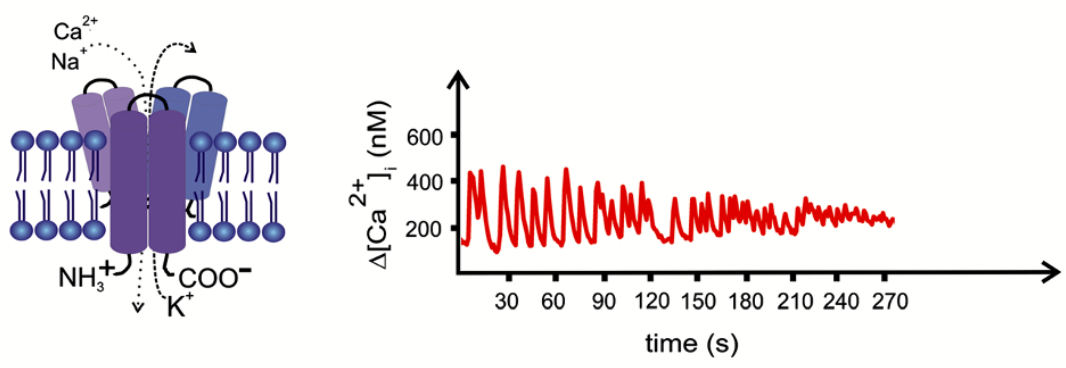

B

$$
\text { P2Y1,2,4,6,11-14 } \longrightarrow \text { Calcium Waves }
$$
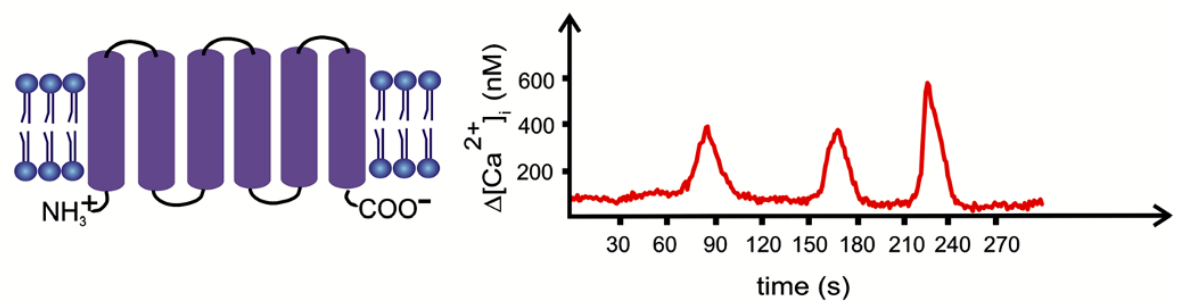

Figure 1 Oscillations of $\left[\mathrm{Ca}^{2+}\right]_{\mathbf{i}}$ levels and purinergic receptors. Ionotropic P2X receptors trigger calcium spikes characterized by amplitudes and frequency (A), while metabotropic P2Y receptors induce calcium waves with lower amplitudes and frequencies (B). P2X receptors are composed of three subunits, with two transmembrane loops each. G protein-coupled metabotropic P2Y receptors are composed of 7 transmembrane loops. 
directing of migration and neurogenesis, such as shown for P2Y1 receptors in radial glial cells during cortex development [6].

Ionotropic purinergic receptors were also involved in the progress of pluripotent P19 CSC differentiation and neural phenotype determination. Functions of P2X2 and P2X7 receptor subtypes in conditions of down-regulation of receptor gene expression were studied by stable RNA interference. Knock-down of P2X2 receptor expression along neural differentiation resulted in diminished expression of $\beta$-3-tubulin expression indicating interference with the progress of neurogenesis. On the other hand, P2X7 receptor expression and activity was related to induction of proliferation and gliogenesis, since permanent P2X7 receptor RNA interference resulted in reduced 5'-bromo2'-deoxyuridine (BrdU) incorporation and glial fibrillary acidic (GFAP) protein expression [35] (see Figure 2 for a comprehensive scheme of metabotropic and ionotropic purinergic receptor implication in proliferation and differentiation induction of P19 CSC).
Our laboratory has shown that a full-length and an alternatively spliced form of the mouse P2X6 receptor gene are expressed in mouse P19 CSC, an in vitro model for early neuroectodermal differentiation. The truncated alternatively spliced form was present at the undifferentiated stage of P19 CSC, and was predominant compared to the full-length form during the whole course of neuronal differentiation of these cells [37] suggesting that splicing could provide a mechanism for regulation of P2X6 subunit expression and formation of functional P2X receptors with P2X6 subunit contribution.

The involvement of these receptors in ATP-induced $\left[\mathrm{Ca}^{2+}\right]_{\mathrm{i}}$ transients was probed in pharmacological studies. Moreover, embryonic P19 CSC expressed various other functional subtypes including P2Y1, P2Y2 and P2X4 receptors or P2X-heteromultimeric receptors. In neuronaldifferentiated cells, P2Y2, P2Y6, P2X2 and possibly P2X2/ $\mathrm{P} 2 \mathrm{X} 6$ heteromeric receptors were the major mediators of purinergic receptor-mediated $\left[\mathrm{Ca}^{2+}\right]_{i}$ elevations.

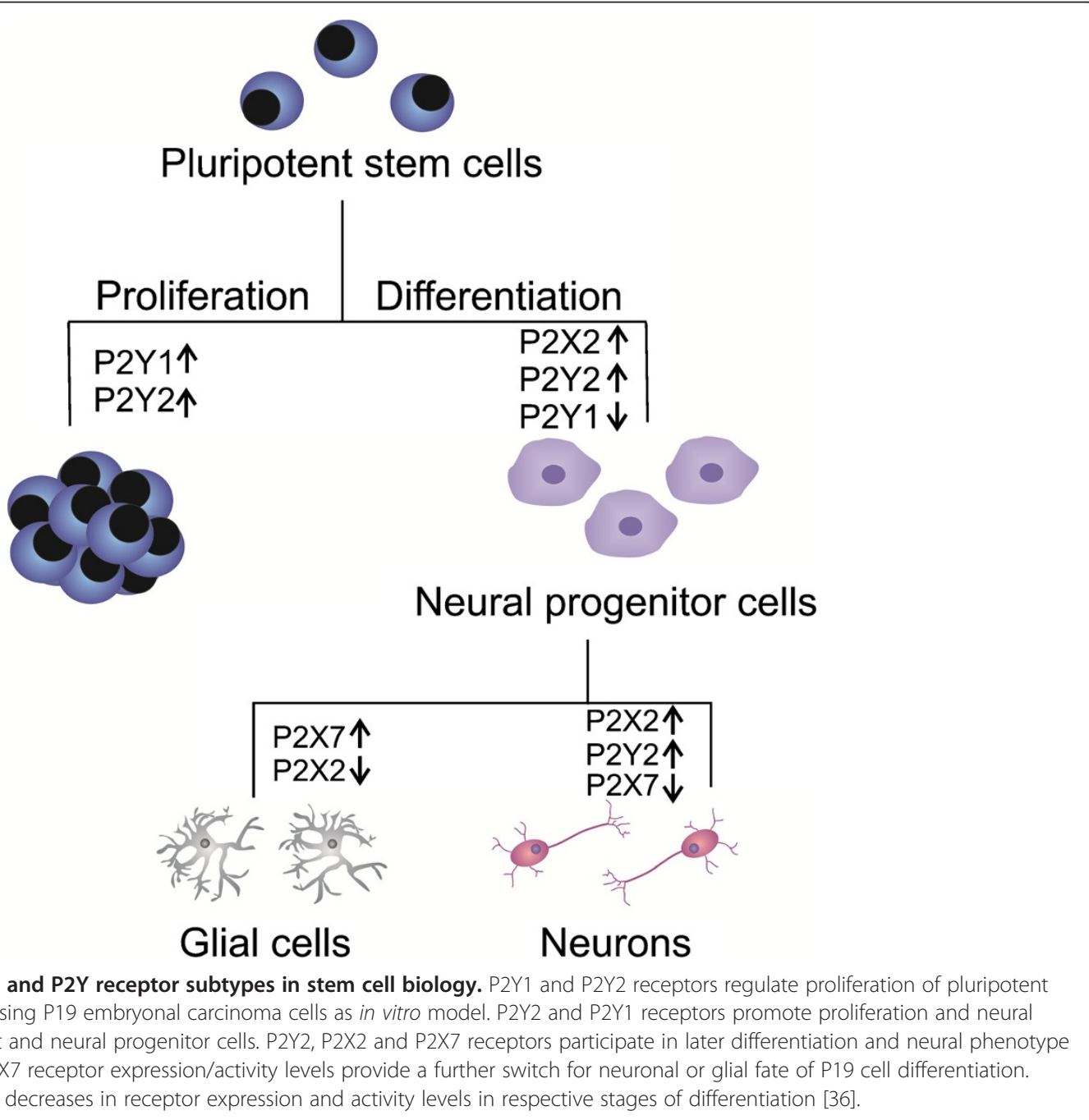


P2Y1 receptor activation produces $\left[\mathrm{Ca}^{2+}\right]_{\mathrm{i}}$ transients which are then propagated in wave form through neighbouring cells by gap junctions and connexin 43hemichannels resulting in cell cycle synchronization of migrating neural progenitors and radial glia cells in the subventricular zone for cortex development [6]. ATP has also been shown to induce proliferation of human neural stem cells (NSC) cultured from telencephalon tissues from a 15-week gestational age embryo [38]. P2Y1 receptor-mediated $\left[\mathrm{Ca}^{2+}\right]_{\mathrm{i}}$ transients resulted in $\mathrm{Ca}^{2+} /$ calmodulin (CAM)-dependent protein kinase II (CaMKII) activation in cell soma and neurites of cerebellar granule neurons, followed by cAMP/Ca ${ }^{2+}$ response element binding protein $(\mathrm{CREB})$ phosphorylation and modulation of gene transcription [39]. Neurotrophic effects, such as observed in Neuro2A cells, were induced by P2Y1 receptor signaling [40]. Here, low-frequency global and local $\mathrm{Ca}^{2+}$ transients induced by purinergic receptor activation during early stages of differentiation of neural progenitor cells promoted neurite outgrowth and the onset of GABAergic neurotransmitter phenotype specification. Surprisingly, spontaneous $\mathrm{Ca}^{2+}$ signals in individual precursors were not synchronized with $\mathrm{Ca}^{2+}$ transients in surrounding cells, indicating the existence of a different pathway, not depending on connexin 43-hemichannel-mediated intercellular $\mathrm{Ca}^{2+}$ signaling [41].

Calcium ions also plays an important role in proliferation and differentiation of hMSCs. Spontaneous $\left[\mathrm{Ca}^{2+}\right]_{\mathrm{i}}$ oscillations occur without agonist stimulation in hMSCs. These $\left[\mathrm{Ca}^{2+}\right]_{\mathrm{i}}$ transient are mediated by IP3induced $\mathrm{Ca}^{2+}$ release and controlled by an autocrine/ paracrine signaling pathway in which ATP is secreted via a hemi-gap junction channel and then stimulates the $\mathrm{P}_{2} \mathrm{Y}_{1}$ receptor, resulting in the activation of $\mathrm{PLC}-\beta$ for IP3 production. Furthermore, $\left[\mathrm{Ca}^{2+}\right]_{\mathrm{i}}$ oscillations are associated with nuclear factor of activated T-cell (NFAT) translocation into the nucleus of undifferentiated hMSCs, providing a new role for $\left[\mathrm{Ca}^{2+}\right]_{\mathrm{i}}$ oscillations in such stem cells [42].

The P2Y2 receptor subtype, another purinergic receptor involved in neural differentiation, which activates of PLC- $\beta$, intracellular $\mathrm{Ca}^{2+}$ release and intercellular $\mathrm{Ca}^{2+}$ waves, important for embryonic development [43]. However in neural stem cells, Lin and coworkers [44] described that neural progenitor proliferation is modulated by an autocrine loop. These cells release ATP and thus activate P2Y receptors for proliferation maintenance. Blockade of proliferation and induction to neural differentiation occurred only when purinergic receptor activity had been antagonized and $\left[\mathrm{Ca}^{2+}\right]_{\mathrm{i}}$ transients had diminished.

In undifferentiated P19 CSC, ATP provoked acceleration of proliferation via $\mathrm{P} 2 \mathrm{Y} 1$ and $\mathrm{P} 2 \mathrm{Y} 2$ receptor activation. P19 CSC that progressed to the progenitor stage revealed down-regulated P2Y1 receptor expression, while activation of IP3-sensitive intracellular $\mathrm{Ca}^{2+}$ stores was mediated by $\mathrm{P} 2 \mathrm{Y} 2$ receptors. The progress of neuronal differentiation and phenotype transition was determined by analysis of nestin and neuron-specific enolase gene and protein expression levels $[27,45]$.

\section{Activation of transcription factors by ICS}

It is important to highlight that during differentiation many immediate early genes are activated in order to regulate cell's genomic responses to environmental stimuli. Underlying intracellular mechanisms are not clear yet; however, Sheng and coworkers showed that c-fos expression, an immediate early gene, depends on calcium influx. This increase activates the calcium response element (CaRE) and thus results in phosphorylation/activation of the CaRE binding protein and consequently c-fos transcription [46].

The transcription factor CREB is activated in neurons in response to trans-synaptic signaling and regulates the expression of genes important for adaptive neuronal responses, such as behavioral adaptation to changes in the environment [47], as well as for more complex neural functions, such as learning and memory formation [48]. Target genes include immediate early genes, such as c-fos [46], and molecules essential for synaptic function, including brain derived neurotrophic factor (BDNF) [49,50] and neuronal nitric oxide synthase (nNOS) [51]. In addition to its functions in mature neurons, CREB regulates cell proliferation, differentiation, and survival responses in a range of cell types in developing vertebrates [52-54]. CREB is inactive as a transcription factor until a cell is exposed to any one of a range of extracellular stimuli that trigger CREB phosphorylation at a specific site. Ser133 within its kinaseinducible domain promotes association of CREB with a co-adaptor protein, the CREB binding protein (CBP). The recruitment of CBP by CREB to the promoter of a CREB target gene then induces the assembly of an active polymerase II transcription complex, thus leading to target gene activation [55]. The kinetics of CREB Ser142 and Ser143 phosphorylation suggest that, when both of these phosphorylation events occur together with Ser133 phosphorylation, they promote CREB activation [56]. Moreover, experimental evidence indicates that $\mathrm{Ca}^{2+}$ / CaM dependent kinase IV (CaMKIV) and CREB play a critical role in mediating calcium-induced dendritic growth in cortical neurons. A constitutively active form of CaMKIV induces dendritic growth in the absence of extracellular stimulation and activates the transcription factor CREB [57].

In hippocampal neurons, signaling to CREB activation can be triggered by elevations in nuclear calcium concentration alone and does not require import of cytoplasmic proteins into the nucleus. The nucleus is particularly 
suited to integrate neuronal firing patterns, and specifies the transcriptional outputs through a burst frequency and nuclear calcium amplitude conversion. Calcium release from intracellular stores promotes calcium wave propagation into the nucleus, which is critical for CREB-mediated transcription by synaptic receptors. Pharmacological modulation of nuclear calcium or modulation of gene expression levels of proteins involved in this process may directly affect stem cell differentiation during development [58].

Another important regulatory molecule that is sensible to changes in $\left[\mathrm{Ca}^{2+}\right]_{\mathrm{i}}$ is the transcription factor myocyte enhancer factor-2 (MEF2), which is highly expressed in neurons and during embryogenesis. Experimental evidence indicates roles for MEF2 as a calcium-dependent regulator of neuronal differentiation and function. The calcium-binding protein $\mathrm{CaM}$ is activated by signals that trigger rises in $\left[\mathrm{Ca}^{2+}\right]_{i}$ resulting in $\mathrm{Ca}^{2+}$-bound $\mathrm{CaM}$ association with calcineurin $(\mathrm{Cn})$, and thus releases $\mathrm{Cn}$ from its repressive effects. Cn dephosphorylates NFAT and MEF2, allowing them to translocate into the nucleus and consequently switch on gene transcription [59]. When $\mathrm{Ca}^{2+}$ entry is prevented or Cn activity is inhibited, NFAT is rephosphorylated by NFAT kinases and rapidly leaves the nucleus (t1/2 $15 \mathrm{~min}$ ), and NFAT-dependent gene expression is terminated [60-63]. As a result of this absolute dependence on $\mathrm{Ca}^{2+} / \mathrm{Cn}$ signaling, NFAT has a remarkable ability to sense dynamic changes in intracellular $\mathrm{Ca}^{2+}$ levels and frequencies of $\mathrm{Ca}^{2+}$ oscillations in cells [64] (Figure 3). Furthermore, activation of CaMKII, through high-amplitude calcium spikes [65], induces neural gene expression through transcription factors of the MEF2 family [59].

Gene expression induced by $\left[\mathrm{Ca}^{2+}\right]_{\mathrm{i}}$ transients, triggered by activation of VOCs and [66] and purinergic P2X or P2Y receptors, could comprise general regulation

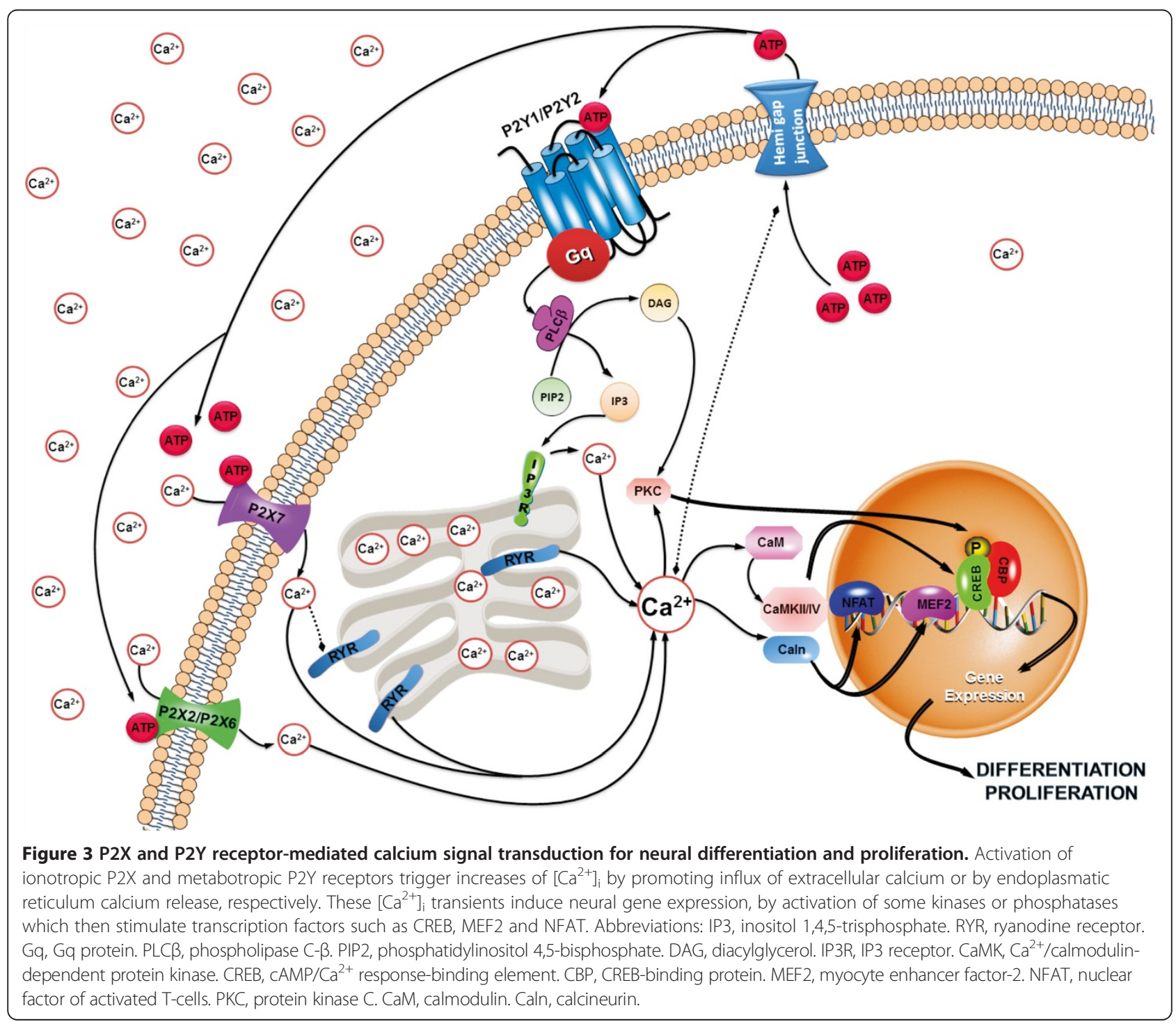


mechanisms of neural differentiation. Such hypothesis is in agreement with the observation that purinergic signaling is present and critical in switching on genes for development of the nervous system and the eye of the Xenopus around the time of gastrulation [67-69]. $\mathrm{Ca}^{2+}$ waves occur during early development, between stages 9 and 12 in the dorsal ectoderm of Хепориs [70]. From stage 10 onwards, $\left[\mathrm{Ca}^{2+}\right]_{\mathrm{i}}$ transients are limited to regions of forebrain, midbrain and eyes overlapping with the approximate location and time of ATP release $[69,71]$. The relationship between P2 receptor and transcription factor activation by ICS is well illustrated in Figure 3.

\section{Conclusions}

ICS is an important issue to study because of its versatility, which controls different cell processes essential for cellular function, including stem cell differentiation. Much evidence points at an important physiological role of extracellular ATP during neuronal development by stimulating proliferation and/or differentiation of NSC and progenitor cells depending on the repertoire of P2 receptor subtype expression. Agonists and antagonists might provide novel and powerful tools for modulating these cell functions for therapy of developmental diseases and regeneration therapy in neurodegenerative diseases. P2X and P2Y purinergic receptors promote proliferation by a mechanism in which ATP induces increases in $\left[\mathrm{Ca}^{2+}\right]_{\mathrm{i}}$ in form of waves or spikes, leading to activation of various effectors, followed by an alteration in transcription factor expression and activity patterns such as CREB, NFAT and MEF2, which are involved in stimulation of neural gene transcription. Better understanding of these processes will establish the importance of purinergic signaling in stem cell biology.

\begin{abstract}
Abbreviations
$\left[\mathrm{Ca}^{2+}\right]$ i: Cytosolic free $\mathrm{Ca}^{2+}$ concentration; ADP: Adenosine 5'-diphosphate; AMP: Adenosine monophosphate; ATP: Adenosine 5'-triphosphate; BDNF: Brain derived neurotrophic factor; CAM: Calmodulin; $\mathrm{CaMK}_{\mathrm{C}} \mathrm{Ca}^{2+} /$ Calmodulin dependent kinase; CaRE: Calcium response element; CBP: CREB binding protein; Cn: Calcineurin; CREB: Camp/ $\mathrm{Ca}^{2+}$ response element binding protein;

CSC: Embryonal carcinoma cells; ER: Endoplasmic reticulum; hMSC: Adult bone marrow mesenchymal; ICS: Intracellular calcium signaling; IP3: Inositol-1,4, 5-Trisphosphate; MEF2: Myocyte enhancer factor-2; NFAT: Nuclear factor of activated T-Cells; nNOS: neuronal nitric oxide synthase; PLC- $\beta$ : PhospholipaseC- $\beta$; ROCs: Receptor-operated channels; RYR: Ryanodine receptor; UDP: Uridine-5'diphosphate; UTP: Uridine-5'-triphosphate; VOCs: Voltage-operated channels.
\end{abstract}

\section{Competing interests}

The authors declare to have no competing interests.

\section{Authors' contribution}

All authors contributed to the writing of the manuscript. Figures 1-3 were designed by T.G. All authors read and approved the final manuscript.

\section{Acknowledgments}

H.U. acknowledges grant support from Fundação de Amparo à Pesquisa do Estado de São Paulo (FAPESP), Project No. 2006/61285-9 and 2012/50880-4, Conselho Nacional de Desenvolvimento Científico e Tecnológico (CNPq), and the Provost's Office for Research of the University of São Paulo (Programa de Incentivo à Pesquisa, Project No. 2011.1.9333.1.3, NAPNA-USP), Brazil. R.R.R. is grateful for grant support by CNPq-MCT and Instituto Nacional de Ciência e Tecnologia de Nanomateriais de Carbono, CNPq and Fundação de Amparo à Pesquisa do Estado de Minas Gerais (FAPEMIG), Brazil. T.G.'s doctoral thesis is supported by a fellowship from FAPESP.

\section{Author details}

'Departamento de Bioquímica, Instituto de Química, Universidade de São Paulo, Avenida Professor Lineu Prestes, 748, São Paulo CEP 05508-900, Brazil. ${ }^{2}$ Departamento de Bioquímica e Imunologia, Instituto de Ciências Biológicas, Universidade Federal de Minas Gerais, Belo Horizonte, Brazil.

Received: 3 September 2012 Accepted: 4 February 2013

Published: 17 February 2013

\section{References}

1. Berridge MJ: Elementary and global aspects of calcium signalling. J Exp Biol 1997, 200:315-319.

2. Berridge MJ, Lipp P, Bootman MD: The versatility and universality of calcium signalling. Nat Rev Mol Cell Biol 2000, 1:11-21.

3. Berridge MJ: Inositol trisphosphate and calcium signalling. Nature 1993, 361:315-325.

4. Clapham DE: Calcium signaling. Cell 1995, 80:259-268.

5. Spitzer NC, Lautermilch NJ, Smith RD, Gomez TM: Coding of neuronal differentiation by calcium transients. Bioessays 2000, 22:811-817.

6. Ulrich H, Abbracchio MP, Burnstock G: Extrinsic Purinergic Regulation of Neural Stem/Progenitor Cells: Implications for CNS Development and Repair. Stem Cell Reviews and Reports 2012, 8(3):755-67.

7. Spitzer NC, Root CM, Borodinsky LN: Orchestrating neuronal differentiation: patterns of $\mathrm{Ca} 2+$ spikes specify transmitter choice. Trends Neurosci 2004, 27:415-421.

8. Resende RR, da Costa JL, Kihara AH, Adhikari A, Lorencon E: Intracellular $\mathrm{Ca} 2+$ regulation during neuronal differentiation of murine embryonal carcinoma and mesenchymal stem cells. Stem Cells Dev 2010, 19:379-394.

9. Resende RR, Adhikari A, da Costa JL, Lorencon E, Ladeira MS, Guatimosim S, Kihara AH, Ladeira LO: Influence of spontaneous calcium events on cellcycle progression in embryonal carcinoma and adult stem cells. Biochim Biophys Acta 2010, 1803:246-260.

10. Lipp P, Thomas D, Berridge MJ, Bootman MD: Nuclear calcium signalling by individual cytoplasmic calcium puffs. EMBO J 1997, 16:7166-7173.

11. Spitzer NC: Activity-dependent neuronal differentiation prior to synapse formation: the functions of calcium transients. J Physiol Paris 2002, 96:73-80.

12. Tonelli FM, Santos AK, Gomes DA, da Silva SL, Gomes KN, Ladeira LO, Resende RR: Stem cells and calcium signaling. Adv Exp Med Biol 2012, 740:891-916.

13. Burnstock $\mathrm{G}$ : The past, present and future of purine nucleotides as signalling molecules. Neuropharmacology 1997, 36:1127-1139.

14. Verkhratsky A, Krishtal OA, Burnstock G: Purinoceptors on neuroglia. Mol Neurobiol 2009, 39:190-208.

15. Burnstock G, Campbell G, Satchell D, Smythe A: Evidence that adenosine triphosphate or a related nucleotide is the transmitter substance released by non-adrenergic inhibitory nerves in the gut. Br J Pharmacol 1970, 40:668-688.

16. North RA: P2X receptors: a third major class of ligand-gated ion channels. CIBA Found Symp 1996, 198:91-105. discussion 105-109.

17. Egan TM, Khakh BS: Contribution of calcium ions to P2X channel responses. J Neurosci 2004, 24:3413-3420.

18. Burnstock G: Purinergic signalling. Br J Pharmacol 2006, 147(Suppl 1):S172-S181.

19. Burnstock G: Pathophysiology and therapeutic potential of purinergic signaling. Pharmacol Rev 2006, 58:58-86.

20. Dona F, Ulrich H, Persike DS, Conceicao IM, Blini JP, Cavalheiro EA, Fernandes MJ: Alteration of purinergic P2X4 and P2X7 receptor expression in rats with temporal-lobe epilepsy induced by pilocarpine. Epilepsy Res 2009, 83:157-167.

21. Glaser T, Cappellari AR, Pillat MM, Iser IC, Wink MR, Battastini AM, Ulrich H: Perspectives of purinergic signaling in stem cell differentiation and tissue regeneration. Purinergic Signal 2012, 8(3):523-37.

22. Majumder P, Trujillo CA, Lopes CG, Resende RR, Gomes KN, Yuahasi KK, Britto LR, Ulrich $\mathrm{H}$ : New insights into purinergic receptor signaling in 
neuronal differentiation, neuroprotection, and brain disorders. Purinergic Signal 2007, 3:317-331.

23. Dubyak GR, El-Moatassim C: Signal transduction via P2-purinergic receptors for extracellular ATP and other nucleotides. Am J Physiol 1993 265:C577-606

24. Abbracchio MP, Burnstock G, Boeynaems JM, Barnard EA, Boyer JL, Kennedy C, Knight GE, Fumagalli M, Gachet C, Jacobson KA, Weisman GA: International Union of Pharmacology LVIII: update on the P2Y G proteincoupled nucleotide receptors: from molecular mechanisms and pathophysiology to therapy. Pharmacol Rev 2006, 58:281-341.

25. Burnstock $\mathrm{G}$ : Physiology and pathophysiology of purinergic neurotransmission. Physiol Rev 2007, 87:659-797.

26. Burnstock G: Purine and pyrimidine receptors. Cell Mol Life Sci 2007 64:1471-1483.

27. Resende RR, Majumder P, Gomes KN, Britto LR, Ulrich H: P19 embryonal carcinoma cells as in vitro model for studying purinergic receptor expression and modulation of $\mathrm{N}$-methyl-D-aspartate-glutamate and acetylcholine receptors during neuronal differentiation. Neuroscience 2007, 146:1169-1181

28. Czyz J, Wobus A: Embryonic stem cell differentiation: the role of extracellular factors. Differentiation 2001, 68:167-174.

29. Watt FM, Hogan BL: Out of Eden: stem cells and their niches. Science 2000, 287:1427-1430.

30. Mironov SL: Metabotropic ATP receptor in hippocampal and thalamic neurones: pharmacology and modulation of $\mathrm{Ca} 2+$ mobilizing mechanisms. Neuropharmacology 1994, 33:1-13.

31. Salter MW, Hicks JL: ATP causes release of intracellular Ca2+ via the phospholipase C beta/IP3 pathway in astrocytes from the dorsal spinal cord. J Neurosci 1995, 15:2961-2971.

32. Schwindt TT, Trujillo CA, Negraes PD, Lameu C, Ulrich H: Directed differentiation of neural progenitors into neurons is accompanied by altered expression of P2X purinergic receptors. J Mol Neurosci 2011, 44:141-146.

33. Shukla V, Zimmermann H, Wang L, Kettenmann H, Raab S, Hammer K, Sevigny J, Robson SC, Braun N: Functional expression of the ecto-ATPase NTPDase2 and of nucleotide receptors by neuronal progenitor cells in the adult murine hippocampus. J Neurosci Res 2005, 80:600-610.

34. Suadicani SO, Brosnan CF, Scemes E: P2X7 receptors mediate ATP release and amplification of astrocytic intercellular Ca2+ signaling. J Neurosci 2006, 26:1378-1385.

35. Yuahasi KK, Demasi MA, Tamajusuku AS, Lenz G, Sogayar MC, Fornazari M, Lameu C, Nascimento IC, Glaser T, Schwindt TT, et al: Regulation of neurogenesis and gliogenesis of retinoic acid-induced P19 embryonal carcinoma cells by $\mathrm{P} 2 \mathrm{X} 2$ and $\mathrm{P} 2 \mathrm{X} 7$ receptors studied by RNA interference. Int J Dev Neurosci 2012, 30:91-97.

36. Ulrich H: Purinergic receptors in stem cell biology. In (Org.). Stem Cells and Cancer Stem Cells, vol. 8. 1st edition. Edited by Hayat MA. Dordrecht: Springer; 2012:267-274

37. da Silva $R L$, Resende $R R$, Ulrich $H$ : Alternative splicing of $\mathrm{P} 2 \mathrm{X} 6$ receptors in developing mouse brain and during in vitro neuronal differentiation. Exp Physiol 2007, 92:139-145.

38. Ryu JK, Choi HB, Hatori K, Heisel RL, Pelech SL, McLarnon JG, Kim SU: Adenosine triphosphate induces proliferation of human neural stem cells: Role of calcium and p70 ribosomal protein S6 kinase. J Neurosci Res 2003, 72:352-362

39. Leon D, Hervas C, Miras-Portugal MT: P2Y1 and P2X7 receptors induce calcium/calmodulin-dependent protein kinase II phosphorylation in cerebellar granule neurons. Eur J Neurosci 2006, 23:2999-3013.

40. Lakshmi S, Joshi PG: Activation of Src/kinase/phospholipase C/mitogenactivated protein kinase and induction of neurite expression by ATP, independent of nerve growth factor. Neuroscience 2006, 141:179-189.

41. Ciccolini F, Collins TJ, Sudhoelter J, Lipp P, Berridge MJ, Bootman MD: Loca and global spontaneous calcium events regulate neurite outgrowth and onset of GABAergic phenotype during neural precursor differentiation. $J$ Neurosci 2003, 23:103-111.

42. Kawano S, Otsu K, Kuruma A, Shoji S, Yanagida E, Muto Y, Yoshikawa F, Hirayama Y, Mikoshiba K, Furuichi T: ATP autocrine/paracrine signaling induces calcium oscillations and NFAT activation in human mesenchymal stem cells. Cell Calcium 2006, 39:313-324.

43. Webb SE, Miller AL: Calcium signalling during embryonic development. Nat Rev Mol Cell Biol 2003, 4:539-551.
44. Lin JH, Takano T, Arcuino G, Wang X, Hu F, Darzynkiewicz Z, Nunes M Goldman SA, Nedergaard M: Purinergic signaling regulates neural progenitor cell expansion and neurogenesis. Dev Biol 2007, 302:356-366

45. Resende RR, Britto LR, Ulrich H: Pharmacological properties of purinergic receptors and their effects on proliferation and induction of neuronal differentiation of P19 embryonal carcinoma cells. Int J Dev Neurosci 2008, 26:763-777.

46. Sheng M, McFadden G, Greenberg ME: Membrane depolarization and calcium induce c-fos transcription via phosphorylation of transcription factor CREB. Neuron 1990, 4:571-582.

47. Ginty DD, Kornhauser JM, Thompson MA, Bading H, Mayo KE, Takahashi JS, Greenberg ME: Regulation of CREB phosphorylation in the suprachiasmatic nucleus by light and a circadian clock. Science 1993 260:238-241.

48. Frank DA, Greenberg ME: CREB: a mediator of long-term memory from mollusks to mammals. Cell 1994, 79:5-8.

49. Shieh PB, Hu SC, Bobb K, Timmusk T, Ghosh A: Identification of a signaling pathway involved in calcium regulation of BDNF expression. Neuron 1998, 20:727-740.

50. Tao X, Finkbeiner S, Arnold DB, Shaywitz AJ, Greenberg ME: Ca2+ influx regulates BDNF transcription by a CREB family transcription factordependent mechanism. Neuron 1998, 20:709-726.

51. Sasaki M, Gonzalez-Zulueta M, Huang H, Herring WJ, Ahn S, Ginty DD, Dawson $V L$, Dawson TM: Dynamic regulation of neuronal NO synthase transcription by calcium influx through a CREB family transcription factor-dependent mechanism. Proc Natl Acad Sci U S A 2000, 97:8617-8622

52. Bonni A, Brunet A, West AE, Datta SR, Takasu MA, Greenberg ME: Cell survival promoted by the Ras-MAPK signaling pathway by transcriptiondependent and -independent mechanisms. Science 1999, 286:1358-1362.

53. Riccio A, Ahn S, Davenport CM, Blendy JA, Ginty DD: Mediation by a CREB family transcription factor of NGF-dependent survival of sympathetic neurons. Science 1999, 286:2358-2361.

54. Walton M, Woodgate AM, Muravlev A, Xu R, During MJ, Dragunow M: CREB phosphorylation promotes nerve cell survival. J Neurochem 1999, 73:1836-1842

55. Kwok RP, Lundblad JR, Chrivia JC, Richards JP, Bachinger HP, Brennan RG, Roberts SG, Green MR, Goodman RH: Nuclear protein CBP is a coactivator for the transcription factor CREB. Nature 1994, 370:223-226.

56. Kornhauser JM, Cowan CW, Shaywitz AJ, Dolmetsch RE, Griffith EC, Hu LS, Haddad C, Xia Z, Greenberg ME: CREB transcriptional activity in neurons is regulated by multiple, calcium-specific phosphorylation events. Neuron 2002, 34:221-233.

57. Redmond L, Kashani AH, Ghosh A: Calcium regulation of dendritic growth via CaM kinase IV and CREB-mediated transcription. Neuron 2002, 34:999-1010.

58. Hardingham GE, Arnold FJ, Bading H: Nuclear calcium signaling controls CREB-mediated gene expression triggered by synaptic activity. Nat Neurosci 2001, 4:261-267.

59. McKinsey TA, Zhang CL, Olson EN: MEF2: a calcium-dependent regulator of cell division, differentiation and death. Trends Biochem Sci 2002, 27:40-47.

60. Garrity PA, Chen D, Rothenberg EV, Wold BJ: Interleukin-2 transcription is regulated in vivo at the level of coordinated binding of both constitutive and regulated factors. Mol Cell Biol 1994, 14:2159-2169.

61. Loh C, Carew JA, Kim J, Hogan PG, Rao A: T-cell receptor stimulation elicits an early phase of activation and a later phase of deactivation of the transcription factor NFAT1. Mol Cell Biol 1996, 16:3945-3954

62. Loh C, Shaw KT, Carew J, Viola JP, Luo C, Perrino BA, Rao A: Calcineurin binds the transcription factor NFAT1 and reversibly regulates its activity. J Biol Chem 1996, 271:10884-10891.

63. Timmerman LA, Clipstone NA, Ho SN, Northrop JP, Crabtree GR: Rapid shuttling of NF-AT in discrimination of $\mathrm{Ca} 2+$ signals and immunosuppression. Nature 1996, 383:837-840.

64. Hogan PG, Chen L, Nardone J, Rao A: Transcriptional regulation by calcium, calcineurin, and NFAT. Genes Dev 2003, 17:2205-2232

65. Lautermilch NJ, Spitzer NC: Regulation of calcineurin by growth cone calcium waves controls neurite extension. J Neurosci 2000, 20:315-325.

66. Canellada A, Cano E, Sanchez-Ruiloba L, Zafra F, Redondo JM: Calciumdependent expression of TNF-alpha in neural cells is mediated by the calcineurin/NFAT pathway. Mol Cell Neurosci 2006, 31:692-701.

67. Bogdanov YD, Dale L, King BF, Whittock N, Burnstock G: Early expression of a novel nucleotide receptor in the neural plate of Xenopus embryos. J Biol Chem 1997, 272:12583-12590. 
68. Cheung KK, Ryten M, Burnstock $G$ : Abundant and dynamic expression of $\mathrm{G}$ protein-coupled P2Y receptors in mammalian development. Dev Dyn 2003, 228:254-266.

69. Masse K, Bhamra S, Eason R, Dale N, Jones EA: Purine-mediated signalling triggers eye development. Nature 2007, 449:1058-1062.

70. Leclerc C, Neant I, Webb SE, Miller AL, Moreau M: Calcium transients and calcium signalling during early neurogenesis in the amphibian embryo Xenopus laevis. Biochim Biophys Acta 2006, 1763:1184-1191.

71. Dale N: Dynamic ATP signalling and neural development. J Physiol 2008, 586:2429-2436.

doi:10.1186/1478-811X-11-12

Cite this article as: Glaser et al:: Implications of purinergic receptor-

mediated intracellular calcium transients in neural differentiation. Cell

Communication and Signaling 2013 11:12.

\section{Submit your next manuscript to BioMed Central and take full advantage of:}

- Convenient online submission

- Thorough peer review

- No space constraints or color figure charges

- Immediate publication on acceptance

- Inclusion in PubMed, CAS, Scopus and Google Scholar

- Research which is freely available for redistribution 